\title{
PENINGKATAN KEDISIPLINAN DATANG DI SEKOLAH MELALUI LAYANAN KONSELING BEHAVIORAL DI SMK
}

\author{
Daroji \\ Sekolah Menengah Kejuruan Negeri 1 Surakarta \\ djdaroji@gmail.com
}

\begin{abstract}
The purpose of this study is to determine the effectiveness of behavioral counseling techniques behavior contract to improve discipline arrive on time at school in class XII student of SMK N 1 Surakarta odd semester of 2014/2015 academic year.This research is a measure of guidance and counseling (PTBK). This study is conducted in two cycles, with each cycle consisting of planning, action, observation, and reflection. The subjects are students of class XII SMK Negeri 1 Surakarta totaling three students. Source of data derived from students. The data collection technique is by observation and interviews. The validity of the data using a triangulation method. Analyzed using percentages and clinical analysis.The results showed that through group counseling to reduce anxiety entering the work of students from pre -cycle to the first cycle and from the first cycle to the second cycle. In the first cycle, the average percentage change of $21.21 \%$. The anxiety of students has decreased, although not significantly. In the second cycle, the average percentage change of $54.33 \%$, which means the results of the research has reached an indicator of success. The conclusions of this research is behavioral counseling with the contract effective technique to improve discipline arrive on time in class XII student of SMK Negeri 1 Surakarta odd semester of 2014/2015 academic year.
\end{abstract}

Keywords: counseling, behavioral contract technique, discipline

\begin{abstract}
ABSTRAK
Tujuan penelitian ini adalah mengetahui keefektifan konseling behavioral teknik kontrak tingkah laku untuk meningkatkan kedisiplinan datang tepat waktu di sekolah pada siswa kelas XII SMK N 1 Surakarta semester gasal tahun pelajaran 2014/2015. Penelitian ini merupakan penelitian tindakan bimbingan dan konseling (PTBK). Penelitian ini dilaksanakan dalam dua siklus, dengan tiap siklus terdiri dari perencanaan, pelaksanaan tindakan, observasi, dan refleksi. Subjek penelitian adalah siswa kelas XII SMK Negeri 1 Surakarta yang berjumlah 3 siswa. Sumber data berasal dari siswa. Teknik pengumpulan data adalah dengan observasi dan wawancara. Validitas data menggunakan triangulasi metode. Analisis data menggunakan analisis persentase dan analisis klinis. Hasil penelitian menunjukkan
\end{abstract}


bahwa melalui konseling kelompok dengan dapat mengurangi kecemasan memasuki dunia kerja siswa dari prasiklus ke siklus I dan dari siklus I ke siklus II. Pada siklus I, rata-rata prosentase perubahan sebesar 21,21\%. Kecemasan siswa sudah berkurang meskipun belum signifikan. Pada siklus II, rata-rata prosentase perubahan sebesar 54,33 \% yang berarti hasil tersebut telah mencapai indikator keberhasilan penelitian. Simpulan penelitian ini adalah konseling behavioral dengan teknik kontrak efektif dapat meningkatkan kedisiplinan datang tepat waktu pada siswa kelas XII SMK Negeri 1 Surakarta semester gasal tahun pelajaran 2014/2015.

Kata kunci: konseling, behavioral teknik kontrak, kedisiplinan

\section{PENDAHULUAN}

Periodisasi perkembangan manusia terbagi menjadi lima periode yaitu masa dalam kandungan, masa kanak-kanak, masa remaja, masa dewasa, dan masa tua. Secara umum perkembangan individu digambarkan dalam periodisasi dengan perkiraan rentang usia di setiap periodenya. Santrock (terjemahan Mila Rachmawati \& Anna Kuswanti, 2007) menjelaskan bahwa penggolongan periode perkembangan yang luas digunakan untuk menggambarkan perkembangan individu yaitu periode prakelahiran, masa bayi, masa kanak-kanak awal, masa kanak-kanak tengah dan akhir, dan masa remaja.

Kelima periode perkembangan individu, periode remaja merupakan periode yang unik dan banyak dibicarakan dalam kehidupan karena masa remaja merupakan masa transisi antara masa anak-anak menuju masa dewasa. Geldard dan Geldard (terjemahan Eka Adinugraha, 2011:5) menjelaskan bahwa "Masa remaja adalah sebuah tahapan dalam kehidupan seseorang yang berada di antara tahap kanak-kanak dan tahap dewasa”. Sedangkan periode perkembangan remaja menurut Santrock (terjemahan Mila Rachmawati \& Anna Kuswanti, 2007:20) adalah peralihan dari masa kanak-kanak menuju masa dewasa awal, berlangsung dari usia 10 hingga 12 tahun dan berakhir pada usia 18 sampai dengan usia 22 tahun. Lebih lanjut dijelaskan oleh Santrock bahwa masa remaja terbagi menjadi tiga tahap yaitu masa pueral, masa pubertas dan adoleses. Masa pueral berlangsung pada usia 12 tahun hingga 14 tahun, masa pubertas dimulai dari usia 14 tahun hingga 18 tahun dan masa adoleses berlangsung dari usia 18 tahun hingga 21 tahun.

Masa pubertas yang berkisar usia antara 14 sampai 18 tahun merupakan masa yang paling rawan dari masa remaja. Dalam masa ini, remaja mengalami banyak perubahan baik perubahan fisik maupun psikis. Muhammad Al-Mighwar (2006: 55) mengemukakan bahwa "remaja merupakan suatu masa perkembangan individu yang ditandai dengan munculnya kematangan secara fisik, akal, kejiwaan dan sosial, serta emosi”.

Dalam masa ini salah satunya dilalui oleh siswa SMK. Dalam perkembangannya siswa SMK memiliki beberapa tugas perkembangan yang harus dicapai. Salah satu tugas perkembangannya yaitu mencapai kematangan dalam sistem etika dan nilai (Havighurs dalam Syamsu Yusuf, 2002). Dalam melaksanakan tugas perkembangannya siswa SMK mengalami banyak permasalahan baik dari dalam dirinya maupun dari lingkungan sekitar. Salah satu 
bentuk permasalahan yang dihadapi siswa SMK adalah datang tidak tepat waktu/terlambat di sekolah.

Siswa yang datang terlambat merupakan hal yang sudah biasa ditemui pada siswa di lingkungan sekolah.Kenyataan tersebut nampak pula terjadi di SMK N 1 Surakarta. Berdasarkan hasil pengamatan guru, sebagian besar siswa di SMK ini melakukan kebiasaan datang terlambat. Permasalahan tersebut perlu mendapat perhatian khusus, karena akan berdampak pada pembentukan karakter siswa dan berdampak pula pada kedisiplinan sekolah. Dengan adanya permasalahan tersebut perlu adanya tindak lanjut dari pihak sekolah terutama guru Bimbingan dan Konseling untuk meningkatkan datang tepat waktu pada siswa. Salah satu layanan dalam Bimbingan dan Konseling yang dapat digunakan untuk permasalahan tersebut yaitu Layanan konseling behavioral.

Menurut layanan konseling behavioral, tingkah laku terbentuk karena adanya faktor pemicu yang disebut antecedent. Sebuah antecedent mendorong terbentuknya perilaku yang disebut behaviour yang selanjutnya akan diikuti oleh consequences. Consequences merupakan bentuk mempengaruhi pengubahan perilaku setelah perilaku terbentuk.

Dalam permasalahan ini, faktor internal siswa dan faktor lingkungan sosial merupakan antecedent yang mempengaruhi terbentuknya perilaku kebiasaan datang terlambat (behaviour). Sedangkan tidak adanya ketegasan dari pihak sekolah merupakan consequences berupa positive reinforcement (penguatan positif) yang menguatkan perilaku berlanjut.

Salah satu teknik dalam konseling behavioral yang dapat digunakan untuk meningkatkan datang tepat waktu di sekolah adalah teknik kontrak tingkah laku. Soeharto dkk (2009:52) berpendapat “Teknik kontrak tingkah laku merupakan salah satu teknik pengubahan tingkah laku yang bertujuan untuk melatih klien agar mampu mengendalikan dan mengarahkan tingkah lakunya sendiri”. Kontrak berarti antara guru BK dengan siswa mengadakan suatu perjanjian atau kerjasama untuk mencapai tujuan yang diharapkan. Kontrak tersebut berisi perjanjian untuk datang tepat waktu di sekolah dilihat dari waktu datang yang disetujui oleh guru BK dan siswa dengan disertai hadiah (reward) dan hukuman (punishment). Hadiah diberikan untuk mendorong siswa menepati perjanjian dan hukuman diberikan kepada siswa apabila melanggar perjanjian yang telah disetujui.

Berdasarkan latar belakang di atas maka dalam penelitian ini peneliti tertarik melakukan penelitian tentang cara meningkatkan kedisiplinan datang tepat waktu pada siswa SMK. Untuk itu peneliti mengambil judul "Peningkatan Kedisiplinan Datang Tepat Waktu di Sekolah melalui Layanan Konseling Behavioral Teknik Kontrak Tingkah Laku pada Siswa Kelas XII SMK N 1 Surakarta Semester Gasal Tahun Pelajaran 2014/2015”.

\section{METODE}

Penelitian ini menggunakan penelitian tindakan bimbingan dan konseling (PTBK) dengan pelaksanaan tindakan dilaksanakan dalam tiga siklus. Setiap siklus terdiri dari empat tahap yaitu tahap perencanaan (planning), tindakan (action), pengamatan (observing), dan refleksi (reflecting). Penelitian ini dilaksanakan di SMK Negeri 1 Surakarta. SMK ini terletak di jalan Sungai Kapuas no. 28, Kelurahan Kedung Lumbu, Kecamatan Pasar Kliwon, Surakarta, Kode Pos 57113. Penelitian dilaksanakan pada semester I tahun pelajaran 2014/2015. 
Teknik pengumpulan data dalam penelitian ini menggunakan observasi dan wawancara dengan uji validitas yaitu menggunakan triangulasi metode dan analisis data menggunakan analisis persentase dan analisis klinis. Indikator hasil capaian sesuai dengan pendapat Godwin dan Coates (1976) yaitu tindakan dikatakan berhasil apabila terjadi perubahan sebesar 50\% dari keadaan sebelum treatment.

\section{HASIL DAN PEMBAHASAN}

Tindakan berupa konseling behavioral dengan teknik kontrak tingkah laku dilaksanakan pada siswa kelas XII dengan subjek penelitian berjumlah 3 siswa. Pemberian tindakan dilaksanakan dalam 2 siklus pada setiap subjek penelitian dalam 2 kali pertemuan/ konseling. Hasil tindakan pada siklus 1 adalah sebagai berikut:

Tabel 1.1. Perbandingan Hasil Observasi dan wawancara Sebelum dan Sesudah Tindakan

\begin{tabular}{|c|c|c|c|c|}
\hline No & Tingkah laku & $\begin{array}{c}\text { Frekuensi } \\
\text { sebelum } \\
\text { tindakan }\end{array}$ & $\begin{array}{c}\text { Frekuensi setelah } \\
\text { tindakan I }\end{array}$ & $\begin{array}{c}\text { Prosentase } \\
\text { Perubahan } \\
\text { Siklus I }\end{array}$ \\
\hline 1 & $\begin{array}{l}\text { Datang ke sekolah sebelum } \\
\text { pukul 07.00 }\end{array}$ & 1,5 & 3,25 & $29 \%$ \\
\hline 2 & Tidur sebelum pukul 21.00 & 0,25 & 1,75 & $25 \%$ \\
\hline 3 & Berpakaian rapi & 2,25 & 3,5 & $21 \%$ \\
\hline 4 & $\begin{array}{l}\text { Terlihat segar/ tidak lesu dan } \\
\text { mengantuk di kelas }\end{array}$ & 2 & 3 & $17 \%$ \\
\hline
\end{tabular}

Tabel 1.2 : Persentase Perubahan Frekuensi datang tepat waktu sebelum tindakan dan sesudah tindakan siklus I atas nama PLN

\begin{tabular}{|c|c|c|c|c|}
\hline No & Tingkah laku & $\begin{array}{c}\text { Frekuensi } \\
\text { sebelum } \\
\text { tindakan }\end{array}$ & $\begin{array}{c}\text { Frekuensi } \\
\text { setelah } \\
\text { tindakan I }\end{array}$ & $\begin{array}{c}\text { Prosentase } \\
\text { Perubahan } \\
\text { Siklus I }\end{array}$ \\
\hline 1 & Datang ke sekolah sebelum pukul 07.00 & 2 & 3,25 & $21 \%$ \\
\hline 2 & Tidur sebelum pukul 21.00 & 1,25 & 2,25 & $17 \%$ \\
\hline 3 & Berpakaian rapi & 2,5 & 4 & $25 \%$ \\
\hline 4 & $\begin{array}{l}\text { Terlihat segar/ tidak lesu dan mengantuk di } \\
\text { kelas }\end{array}$ & 1,75 & 3 & $21 \%$ \\
\hline
\end{tabular}


ISSN: 1907-4034

Tabel 1.3 : Persentase Perubahan Frekuensi datang tepat waktu sebelum tindakan dan sesudah tindakan siklus I atas nama VPB

\begin{tabular}{ccccc}
\hline No & \multicolumn{1}{c}{ Tingkah laku } & $\begin{array}{c}\text { Frekuensi } \\
\text { sebelum } \\
\text { tindakan }\end{array}$ & $\begin{array}{c}\text { Frekuensi setelah } \\
\text { tindakan I }\end{array}$ & $\begin{array}{c}\text { Prosentase } \\
\text { Perubahan } \\
\text { Siklus I }\end{array}$ \\
\hline 1 & $\begin{array}{l}\text { Datang ke sekolah sebelum pukul } \\
07.00\end{array}$ & 0,75 & 3,25 & $42 \%$ \\
2 & $\begin{array}{l}\text { Tidur sebelum pukul 21.00 } \\
3\end{array}$ & 1 & 2 & $17 \%$ \\
4 & $\begin{array}{l}\text { Berpakaian rapi } \\
\text { mengantuk di kelas }\end{array}$ & 3 & 3,5 & $8 \%$ \\
\hline \multicolumn{2}{c}{ Rata-rata Prosentase perubahan } & 2,5 & $13 \%$ \\
\hline
\end{tabular}

Hasil pelaksanaan tindakan siklus I, diperoleh persentase perubahan sbjek sebagai perbandingan perubahan siswa sebelum tindakan dan setelah tindakan siklus 1 .

Tabel 1.4 : Jumlah Rata-Rata Perubahan Keseluruhan Subjek pada Siklus I

\begin{tabular}{cc}
\hline Nama siswa & Persentase Perubahan \\
\hline CH & $23 \%$ \\
PLN & $20,83 \%$ \\
VPB & $19,79 \%$ \\
Jumlah rata-rata perubahan ketiga subjek & $\mathbf{2 1 , 2 1 \%}$ \\
\hline
\end{tabular}

Hasil pada tabel persentase perubahan di atas menunjukkan bahwa masing-masing siswa mengalami peningkatan kedisiplinan datang tepat waktu. Akan tetapi, rata-rata siswa baru mencapai perubahan sebesar 21,21\% dari kondisi sebelum pelaksanaan tindakan. Berdasarkan target yang telah ditetapkan sebelumnya sebagai indikator keberhasilan bahwa masingmasing siswa harus mampu mengalami perubahan peningkatan minimal sebesar 50\%, maka persentase perubahan tersebut belum dapat mencapai target sehingga ke 3 siswa tersebut perlu diberi tindakan lagi yakni konseling behavioral dengan teknik kontrak pada siklus II. Berikut adalah perbandingan hasil observasi sebelum dan sesudah diberikan tindakan konseling kelompok pada siklus II : 
Tabel 1.5 : Persentase Perubahan Subjek pada Siklus II Atas Nama CH

\begin{tabular}{|c|c|c|c|c|}
\hline No & Tingkah laku & $\begin{array}{c}\text { Frekuensi } \\
\text { sebelum } \\
\text { tindakan }\end{array}$ & $\begin{array}{l}\text { Frekuensi setelah } \\
\text { tindakan II }\end{array}$ & $\begin{array}{c}\text { Prosentase } \\
\text { Perubahan } \\
\text { Siklus II }\end{array}$ \\
\hline 1 & $\begin{array}{l}\text { Datang ke sekolah sebelum } \\
\text { pukul } 07.00\end{array}$ & 1,5 & 5,5 & $67 \%$ \\
\hline 2 & Tidur sebelum pukul 21.00 & 0,25 & 4,5 & $71 \%$ \\
\hline 3 & Berpakaian rapi & 2,25 & 5 & $46 \%$ \\
\hline 4 & $\begin{array}{l}\text { Terlihat segar/ tidak lesu dan } \\
\text { mengantuk di kelas }\end{array}$ & 2 & 4,25 & $38 \%$ \\
\hline
\end{tabular}

Rata-rata Prosentase perubahan

$55 \%$

Tabel 1.6 : Persentase Perubahan Subjek pada Siklus II Atas Nama PLN

\begin{tabular}{|c|c|c|c|c|}
\hline No & Tingkah laku & $\begin{array}{l}\text { Frekuensi } \\
\text { sebelum } \\
\text { tindakan }\end{array}$ & $\begin{array}{l}\text { Frekuensi setelah } \\
\text { tindakan II }\end{array}$ & $\begin{array}{c}\text { Prosentase } \\
\text { Perubahan } \\
\text { Siklus II }\end{array}$ \\
\hline 1 & $\begin{array}{l}\text { Datang ke sekolah sebelum pukul } \\
07.00\end{array}$ & 2 & 5,25 & $54 \%$ \\
\hline 2 & Tidur sebelum pukul 21.00 & 1,25 & 5,25 & $67 \%$ \\
\hline 3 & Berpakaian rapi & 2,5 & 4,75 & $38 \%$ \\
\hline 4 & $\begin{array}{l}\text { Terlihat segar/ tidak lesu dan } \\
\text { mengantuk di kelas }\end{array}$ & 1,75 & 4,75 & $50 \%$ \\
\hline
\end{tabular}

Rata-rata Prosentase perubahan

$52 \%$

Tabel 1.7 : Persentase Perubahan Subjek pada Siklus II Atas Nama VPB

\begin{tabular}{|c|c|c|c|c|}
\hline No & Tingkah laku & $\begin{array}{l}\text { Frekuensi } \\
\text { sebelum } \\
\text { tindakan }\end{array}$ & $\begin{array}{l}\text { Frekuensi setelah } \\
\text { tindakan II }\end{array}$ & $\begin{array}{c}\text { Prosentase } \\
\text { Perubahan } \\
\text { Siklus II }\end{array}$ \\
\hline 1 & $\begin{array}{l}\text { Datang ke sekolah sebelum } \\
\text { pukul } 07.00\end{array}$ & 0,75 & 5,5 & $79 \%$ \\
\hline 2 & Tidur sebelum pukul 21.00 & 1 & 4,75 & $63 \%$ \\
\hline 3 & Berpakaian rapi & 3 & 4,75 & $29 \%$ \\
\hline 4 & $\begin{array}{l}\text { Terlihat segar/ tidak lesu dan } \\
\text { mengantuk di kelas }\end{array}$ & 1,75 & 5 & $54 \%$ \\
\hline & Rata-rata Pros & perubahan & & $56 \%$ \\
\hline
\end{tabular}


Berdasarkan tabel di atas didapat jumlah rata-rata perubahan keseluruhan subjek pada siklus II sebagai berikut:

Tabel 1.8 : Jumlah Rata-Rata Perubahan Keseluruhan Subjek

\begin{tabular}{cc}
\hline Nama siswa & $\begin{array}{c}\text { Persentase Perubahan } \\
\text { tingkah laku }\end{array}$ \\
\hline CH & $55 \%$ \\
PLN & $52 \%$ \\
VPB & $56 \%$ \\
Jumlah rata-rata perubahan kes- \\
eluruhan subjek
\end{tabular}

Hasil pada tabel persentase perubahan di atas menunjukkan bahwa masing-masing siswa mengalami peningkatan skor dalam meningkatkan kedisiplinan datang tepat waktu. Rata-rata siswa mencapai perubahan sebesar 54,33 \% dari kondisi sebelum pelaksanaan tindakan. Berdasarkan target yang telah ditetapkan sebelumnya sebagai indikator keberhasilan bahwa masing-masing siswa harus mampu mengalami perubahan peningkatan minimal sebesar 50\%, maka persentase perubahan tersebut telah mencapai target sehingga ke 3 siswa tersebut dikatakan berhasil mencapai perubahan yang signifikan dalam hal

\section{Peningkatan kedisiplinan datang tepat waktu pada siswa.}

Analisis klinis dilakukan untuk mengetahui perubahan perilaku masing-masing subjek dengan cara bertanya kepada orang terdekat subjek dan orang yang mengenali kondisi subjek sebelumnya.

Melihat hasil perlakuan/tindakan yang berupa konseling behavioral dengan teknik kontrak tingkah laku untuk meningkatkan kedisiplinan datang tepat pada siklus II dapat diketahui bahwa sudah mencapai hasil yang signifikan karena mampu mencapai perubahan perilaku lebih dari 50\% yaitu sebesar 54,33 \%. Hal tersebut didukung dengan hasil analisis klinis yang menunjukkan bahwa perlakuan tersebut mampu mengubah perilaku subjek secara signifikan, oleh karena itu treatment pada siklus II dinyatakan berhasil.

\section{Perbandingan Hasil Tindakan Pada Siklus I dan II}

Tindakan pada masing-masing siklus sudah dilaksanakan. Melalui hasil analisis dan refleksi pada tiap sikus diketahui bahwa untuk meningkatkan kedisiplinan datang tepat waktu dibutuhkan dua siklus yaitu siklus I dan siklus II. Kedua siklus tersebut menunjukkan capaian hasil perubahan yang berbeda-beda. Untuk memperjelas hasil tindakan tiap siklus maka perlu dibuat perbandingan hasil tindakan tiap siklus. Berikut adalah tabel dan grafik perbandingan hasil tindakan tiap siklus untuk masing-masing siswa : 
ISSN: 1907-4034

Tabel 1.9 : Perbandingan frekuensi rata-rata sebelum tindakan dan setelah tindakan siswa CH

\begin{tabular}{ccccc}
\hline Waktu & Minggu I & Minggu II & Minggu III & Minggu IV \\
\hline Sebelum tindakan & 5 & 8 & 6 & 5 \\
Setelah tindakan & 21 & 19 & 18 & 19 \\
\hline
\end{tabular}

Perbandingan siklus I dan siklus II berdasarkan data tersebut dapat digambarkan dalam grafik seperti berikut :

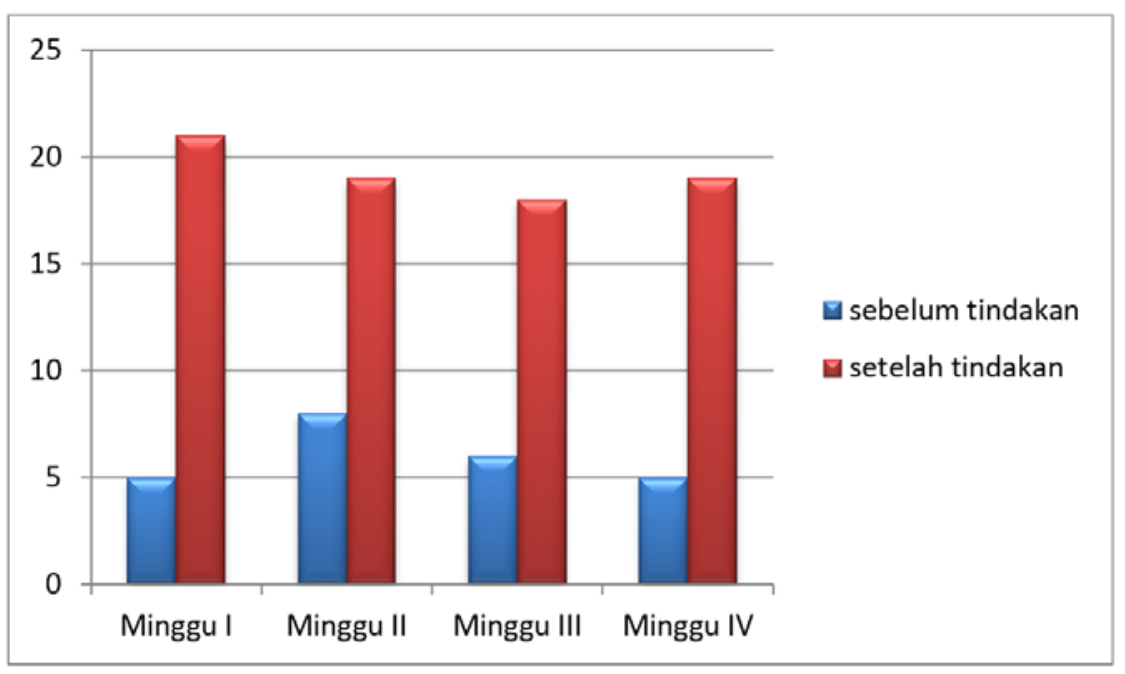

Gambar 1.1 : Histogram Perubahan frekuensi datang tepat waktu siswa CH

Tabel 1.10 : Perbandingan hasil frekuensi rata-rata sebelum tindakan dan setelah tindakan siswa PLN

\begin{tabular}{ccccc}
\hline Waktu & Hari I & Hari II & Hari III & Hari IV \\
\hline Sebelum tindakan & 7 & 7 & 9 & 7 \\
Setelah tindakan & 18 & 21 & 20 & 21 \\
\hline
\end{tabular}


Perbandingan tersebut secara lebih jelas dapat digambarkan dalam grafik sebagai berikut:

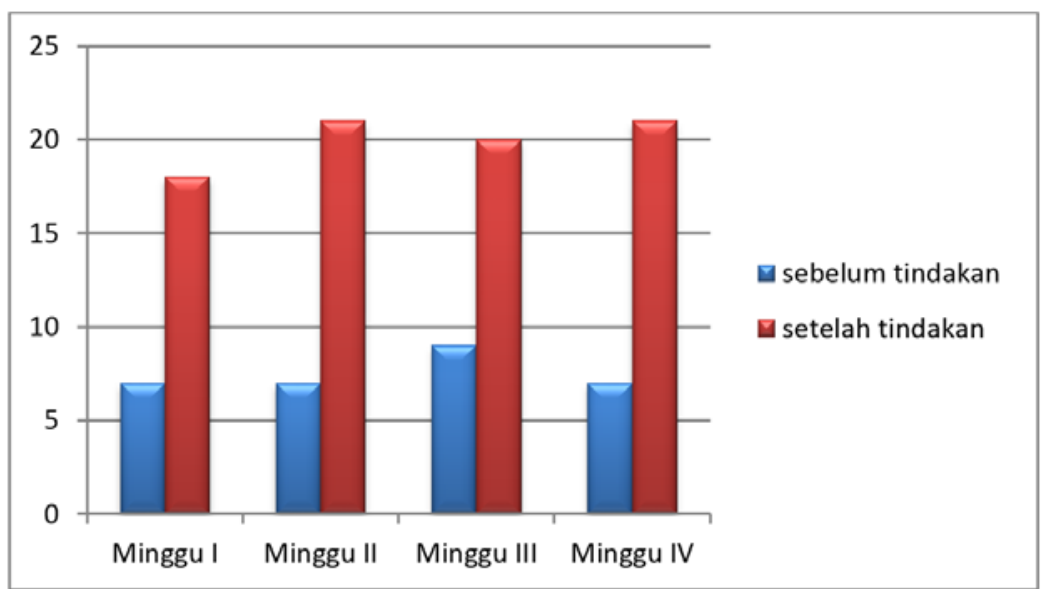

Gambar 1.2 : Histogram Perubahan frekuensi datang tepat waktu siswa PLN

Tabel 1.11: Perbandingan hasil frekuensi rata-rata sebelum tindakan dan setelah tindakan siswa VPB

\begin{tabular}{ccccc}
\hline Waktu & Hari I & Hari II & Hari III & Hari IV \\
\hline Sebelum tindakan & 9 & 5 & 6 & 6 \\
Setelah tindakan & 19 & 20 & 19 & 22 \\
\hline
\end{tabular}

Perbandingan tersebut secara lebih jelas dapat digambarkan dalam grafik sebagai berikut:

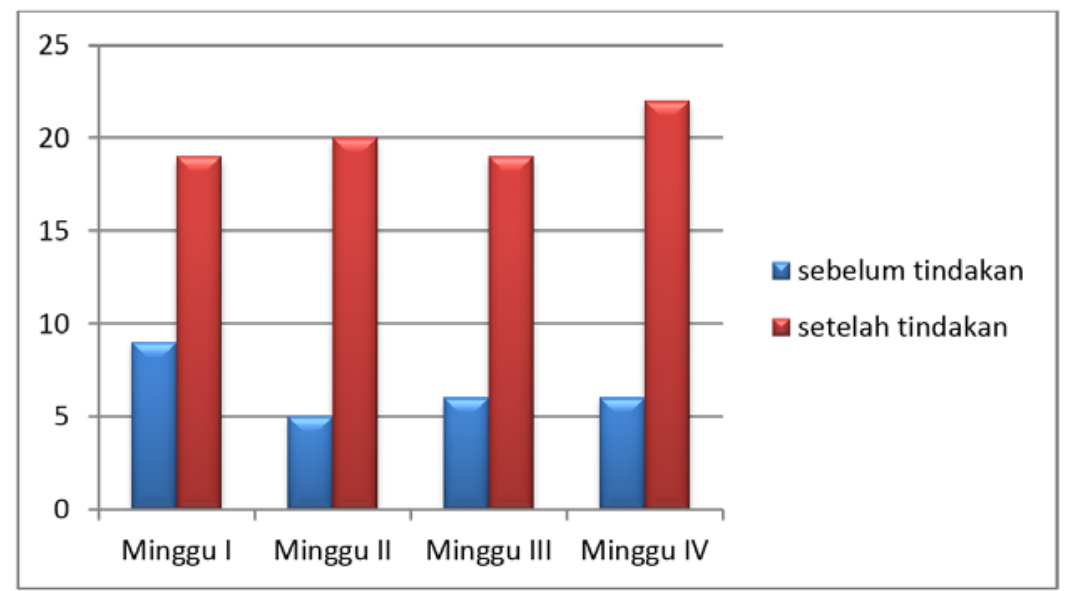

Gambar 4.12: Histogram Perubahan frekuensi datang tepat waktu siswa VPB

Hasil tindakan siklus I dan II di atas menunjukkan bahwa masing-masing subjek penelitian mengalami peningkatan tingkat kedisiplinan datang tepat waktu pada siswa. Hal tersebut dapat dimaknai bahwa hipotesis tindakan pada penelitian ini terbukti kebenarannya, sehingga konseling behavioral dinyatakan efektif untuk meningkatkan kedisiplinan datang tepat waktu pada siswa kelas XII SMK Negeri 1 Surakarta. 
Penelitian ini merupakan penelitian tindakan kelas yang terdiri dari dua siklus yaitu siklus I dan siklus II, dengan tindakan yang berupa konseling behavioral teknik kontrak tingkah laku. Tujuan penelitian ini adalah untuk meningkatkan kedisiplinan datang tepat waktu pada siswa. Hasil penelitian yang telah dilaksanakan selama dua bulan diperoleh perubahan positif yang signifikan yaitu peningkatan kedisiplinan mencapai persentase sebesar 54,33 \% untuk 3 subjek penelitian. Secara rinci perkembangan sebagai hasil perubahan dapat dijelaskan sebagai berikut :

a. Pada siklus I mencapai perubahan sebesar 21,21\%. Hambatan dalam pelaksanaan konseling siklus I yaitu siswa belum paham mengenai proses konseling dan masih ada dukungan perilaku terlambat dari teman siswa. Pada siklus II mencapai perubahan sebesar 54,33 \%. Pelaksanaan tindakan sudah berjalan dengan baik. Siswa mampu meningkatkan kedisiplinan datang tepat waktu. Perubahan tersebut sudah mencapai indikator keberhasilan layanan, sehingga konseling behavioral dengan teknik kontrak efektif untuk meningkatkan kedisiplinan datang tepat waktu pada siswa kelas XII SMK Negeri 1 Surakarta.

b. Berdasarkan hasil pelaksanaan tindakan pada siklus I dan siklus II, dapat dinyatakan bahwa terjadi peningkatan tingkah laku datang tepat waktu siswa dengan menggunakan layanan konseling behavioral teknik kontrak tingkah laku. Setelah konseling dilaksanakan, guru BK melakukan observasi dan wawancara untuk mengetahui tingkat perubahan yang terjadi.

c. Penelitian tentang konseling behavioral dengan teknik kontrak tingkah laku pernah dilakukan oleh Astria (2008) untuk mengubah kecenderungan alkohol. Penelitian yang digunakan adalah penelitian tindakan. Hasil penelitian menunjukkan bahwa terdapat perubahan yang signifikan tentang kecenderungan alkohol pada siswa setelah diberikan tindakan dengan layanan konseling behavioral. Pada pelaksanaan tindakan yang terjadi selama dua siklus, siswa diberi kontrak perjanjian untuk mengubah kecenderungan alkohol dan hasilnya siswa mampu menjalani kontrak dan mengalami perubahan yang signifikan.

\section{SIMPULAN}

1. Konseling behavioral dengan teknik kontrak tingkah laku efektif untuk meningkatkan kedisiplinan datang tepat waktu siswa kelas XII SMK N 1 Surakarta tahun pelajaran 2014/2015. Hal tersebut dapat dibuktikan berdasarkan hasil penelitian yang diperoleh. Hasil penelitian menunjukkan bahwa seluruh subjek penelitian yang berjumlah 3 siswa mengalami peningkatan datang tepat waktu di sekolah.

2. Pelaksanaan tindakan pada siklus I menunjukkan peningkatan tingkah laku datang tepat waktu subjek tetapi belum signifikan, artinya masing-masing subjek mengalami peningkatan masih di bawah 50\%. Peningkatan tersebut belum mencapai indikator keberhasilan yang ditetapkan. Peningkatan rata-rata pada siklus I adalah 21,21\%. Berdasarkan kenyataan tersebut maka perlu diadakan tindakan pada siklus II, dimaksudkan agar tingkah 
laku datang tepat waktu subjek dapat berubah dan meningkat mencapai indikator keberhasilan yaitu 50 \%. Perubahan tingkah laku datang tepat waktu subjek pada siklus II mencapai 54,33 \%. Hasil tersebut menunjukkan bahwa peningkatan perubahan tingkah laku datang tepat waktu subjek sudah signifikan. Hasil analisis klinis juga membuktikan bahwa konseling behavioral dengan teknik kontrak tingkah laku efektif untuk meningkatkan kedisiplinan datang tepat waktu.

\section{DAFTAR PUSTAKA}

Desmita. (2009). Psikologi Perkembangan Peserta Didik : Panduan Bagi Orang Tua dan Guru dalam Memahami Psikologi Anak Usia SD, SMP, dan SMA. Bandung : PT Remaja Rosdakarya.

Dewa Ketut Sukardi.(1987). Bimbingan Karir di Sekolah. Jakarta: Ghalia Indonesia.

Geldard, Kathryn \& Geldard, David. 2010. Konseling Remaja. Yogyakarta: Pustaka Belajar.

Goodwin, Dwight L \& Coates, Thomas J. (1976). Helping Student Help Themselves. New Jersey: Prentice-hall,inc.

Hurlock, Elizabeth. B. (2004). Psikologi Perkembangan Suatu Pendekatan Sepanjang Rentang Kehidupan (alih bahasa Istiwidayanti dan Soedjarwo). Jakarta: Erlangga.

Kartono, Kartini. (2000). Hygiene Mental. Bandung: Mandar Maju.

Langgulung, Hasan. (1986). Teori-teori Kesehatan Mental. Jakarta: Al-Husna.

Lidia Herlin Permata Sari. (2013). Persiapan Siswa dalam Memasuki Dunia Kerja dan Implikasinya Terhadap Pelayanan Bimbingan dan Konseling. Vol 2, No 1 (2013): Konselor. Jurnal. Diperoleh 5 Januari 2014, dari http://portalgaruda.org/index. php?ref=browse \&mod=viewarticle \&article $=24892$

Prayitno. (1999). Dasar- Dasar Bimbingan dan Konseling. Jakarta: Rineka Cipta.

Santrock, John W. 2007. Perkembangan Anak. Jakarta: Erlangga.

Soeharto,dkk. 2009. Bimbingan Konseling. Surakarta: Panitia Sertifikasi Guru Rayon 13 FKIP UNS.

Tohirin. (2007). Bimbingan dan Konseling di Sekolah dan Madrasah Berbasis Integrasi. Jakarta: PT. Raja Grafindo Persada.

Wibowo, Eddy. (2005). Konseling Kelompok Perkembangan. Jakarta: Unres Pres.

Wood, Derek., dkk. (2007). Kiat Mengatasi Gangguan Belajar. Jogjakarta: Kata Hati. 